\title{
Studi Metode Pendinginan Super Cepat untuk Pembentukan Bulk Metallic Glasses pada Paduan $\mathrm{Cu}_{45} \mathrm{Zr}_{45} \mathrm{Al}_{5} \mathrm{Ag}_{5}$
}

\author{
Andromeda Dwi Laksono ${ }^{1}$, Rifqi Aulia Tanjung ${ }^{2}$ \\ ${ }^{1}$ Material and Metallurgical Engineering, Kalimantan Institute of Technology, Balikpapan. Email: \\ andromeda@lecturer.itk.ac.id \\ ${ }^{2}$ Material and Metallurgical Engineering, Kalimantan Institute of Technology, Balikpapan. Email: \\ rifqi.aulia@lecturer.itk.ac.id
}

\begin{abstract}
Bulk metallic glass (BMG) has different mechanical, electrical, magnetic, chemical and physical properties from the general polycrystalline alloy because the internal arrangement of atoms is random. Thus, BMG has well mechanical strength, high hardness, wear resistance, corrosion resistance, and good surface smoothness. Based on these features, BMG has a very promising future in the industry. In this study, a copper mold casting method is used to prepare $\mathrm{Cu}_{45} \mathrm{Zr}_{45} \mathrm{Al}_{5} \mathrm{Ag}_{5}$ BMG. The casting process is followed by giving $-25^{\circ} \mathrm{C}$ ambient temperature with machine cooling. The sample with rod-shape, sizes around 2 to $4 \mathrm{~mm}$ in diameter and $30 \mathrm{~mm}$ in length was successfully produced through copper mold casting method. The rod then sliced into disk-shaped specimens. The BMG sample is validated using Scanning Electron Microscopy (SEM), Energy Dispersion Spectrometer (EDS), Differential Scanning Calorimetry (DSC), Electron Probe X-ray Micro Analyzer (EPMA), and X-ray Diffraction (XRD).
\end{abstract}

Keywords: Bulk Metallic Glasses, $\mathrm{Cu}_{45} \mathrm{Zr}_{45} \mathrm{Al}_{5} \mathrm{Ag}_{5}$, Copper Mold Casting.

\begin{abstract}
Abstrak
Bulk Metallic Glass (BMG) memiliki sifat mekanik, magnetik, kimia dan fisik yang berbeda dengan paduan polikristalin karena susunan internal atomnya yang tidak teratur. Sehingga, BMG memiliki kekuatan mekanik yang baik, kekerasan yang tinggi, ketahanan terhadap aus dan korosi yang tinggi, dan kehalusan permukaan yang baik. Berdasarkan sifat tersebut, BMG memiliki kelayakan yang menjanjikan di bidang industry. Dalam penelitian ini, metode pengecoran cetakan di tembaga digunakan untuk menyiapkan BMG paduan $\mathrm{Cu}_{45} \mathrm{Zr}_{45} \mathrm{Al}_{5} \mathrm{Ag}_{5}$. Paduan dileburkan ulang dengan pendinginan super cepat menggunakan mesin pendingin di bawah temperatur $-25{ }^{\circ} \mathrm{C}$. Dengan metode pengecoran cetakan di tembaga, sampel ukuran besar berbentuk batang dipotong dengan diameter $2 \mathrm{~mm}$ hingga $4 \mathrm{~mm}$ dan panjang $30 \mathrm{~mm}$. Batang kemudian dipotong lagi menjadi spesimen berbentuk cakram. Untuk memastikan apakah sampel adalah BMG atau tidak, sampel dievaluasi dengan Scanning Electron Microscopy (SEM), Energy Dispersion Spectrometer (EDS), Differential Scanning Calorimetry (DSC), Electron Probe X-ray Micro Analyzer (EPMA), dan X -ray Difraction (XRD). Hasilnya dibahas dalam penelitian ini.
\end{abstract}

Kata Kunci: Bulk Metallic Glasses, $\mathrm{Cu}_{45} \mathrm{Zr}_{45} \mathrm{Al}_{5} \mathrm{Ag}{ }_{5}$, Pengecoran Cetakan di Tembaga .

\section{Pendahuluan}

Metallic glasses merupakan generasi baru dalam grup amorfus. Pengembangannya telah dilakukan pada teknik pendinginan antara $10^{5}-10^{6} \mathrm{~K} / \mathrm{s}$. Istilah "bulk" pada metallic glass memiliki syarat minimal diameter atau ketebalan $1 \mathrm{~mm}$ (Suryanarayana \& Inoue, 2011). Beberapa BMG memiliki kekuatan tarik yang baik dengan ketahanan yang baik, kemampuan produksi yang baik, friksi internal yang rendah, dan ketahanan terhadap korosi yang baik. Belakangan ini, BMG digunakan pada bidang industry elektrik. Penelitian mengenai pengembangan pada metallic glasses sudah pernah dilakukan pada awal 1970-an dan 1980-an dengan proses pengecoran pada pembuatan pita metallic glasses, garis tipis logam dan lembaran logam komersial. Hasil penelitian yang menajubkan di bidang akademis dan industri terjadi di periode tersebut. Namun, keterbatasan kecepatan pendinginan yang cepat pada 


\section{Studi Metode Pendinginan Super Cepat untuk Pembentukan Bulk Metallic Glasses pada Paduan $\mathrm{Cu}_{45} \mathrm{Zr}_{45} \mathrm{Al}_{5} \mathrm{Ag}_{5}$}

geometri paduan amorf hanya berlaku untuk lembaran dan garis tipis. Aplikasi untuk ukuran yang lebih besar masih dalam tahapan penelitian dan pengembangan (Wang dkk., 2004).

Aplikasi BMG diharapkan dapat dilakukan pada penyambungan material. Penelitian sebelumnya menunjukkan bahwa dengan temperatur rendah dapat melakukan proses penyambungan seperti pada proses soldering dengan media solder dan dapat diaplikasikan untuk menyambung BMG dengan BMG lain dan BMG dengan logam kristalin (Nishikawa dkk., 2009). Untuk menghindari rekristalisasi glassy phase diperlukan proses penyambungan pada temperatur rendah seperti proses soldering untuk menyambung BMG. Rekristalisasi glass phase masih di atas temperatur leleh dari soldering sehingga tidak mengubah sifat dari $\mathrm{BMG}$ tersebut. Paduan $\mathrm{CuZr}$ memiliki ketahanan korosi yang baik. Kelebihan dari BMG-CuZr adalah paduan amorfus yang paling sering digunakan karena harga materialnya yang murah, sifat mekaniknya yang baik dan kemampuan glass formng ability (GFA) yang baik terhadap kristalisasi saat fabrikasi (Kai dkk., 2009).

Banyak jenis BMG telah dikembangkan termasuk MgCuY, LaAlNi, ZrAlNiCu, $\mathrm{ZrAlNiCu}(\mathrm{Ti}, \mathrm{Nb}$ ), ZrTiCuNiBe, TiNiCuSn, CuZrTiNi, NdFeCoAl, LaAlNi, FeCoNiZrNbB, FeAlGaPCB, PrCuNiAl, $\mathrm{PdNiCuP}$, dll. Saat ini, tingkat pendinginan kritis terendah untuk pembentukan BMG serendah $0,10 \mathrm{~K} /$ $\mathrm{s}$ untuk paduan $\mathrm{Pd}_{40} \mathrm{Cu}_{30} \mathrm{Ni}_{10} \mathrm{P}_{20}$ dan ketebalan sampel maksimum mencapai nilai sebesar sekitar $10 \mathrm{~cm}$ (Inoue, dkk., 1997). Paduan dengan daerah cair superdingin terbesar dengan temperatur $135 \mathrm{~K}$ adalah $\left(\mathrm{Zr}_{82.5} \mathrm{Ti}_{17.5}\right)_{55}\left(\mathrm{Ni}_{54} \mathrm{Cu}_{46}\right)_{18.75} \mathrm{Be}_{26.25}$ (Johnson, dkk., 1999). Vitalloy 1 (vit1), salah satu BMG yang paling banyak diteliti dengan komposisi $\mathrm{Zr}_{41} \mathrm{Ti}_{14} \mathrm{Cu}_{12.5} \mathrm{Ni}_{10} \mathrm{Be}_{22.5}$. Paduan ini dapat dicetak dalam cetakan di tembaga dalam bentuk fully glassy rods dengan diameter berkisar 5-10 cm. Gambar 1 menunjukkan jenis BMG berbasis $\mathrm{Zr}$ yang sudah dicetak dalam berbagai bentuk. Sifat BMG harus memiliki stabilitas termal yang tinggi dan sifat yang luar biasa terlebih lagi untuk potensi yang cukup besar sebagai bahan rekayasa lanjutan. Bahkan, BMG berbasis-Zr menemukan aplikasi dalam industri hanya 3 tahun setelah penemuannya.

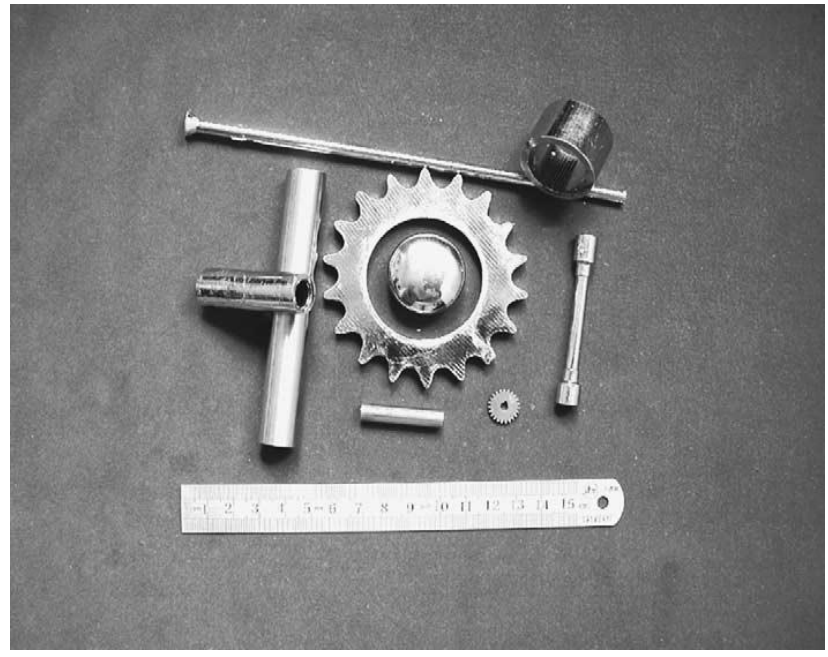

Gambar 1: Cetakan BMG vitalloy

Sumber: (Wang dkk., 2004)

Selama dekade terakhir, berbagai metode telah dikembangkan untuk memproduksi metallic glasses secara massal. Salah satu prinsip panduan umum untuk merancang paduan membentuk BMG adalah pemilihan elemen dengan perbedaan ukuran untuk mencegah terjadinya struktur kompleks mengkristal dengan mudah. Metode lainnya adalah mencari komposisi paduan dengan penentuan eutektik dan membentuk cairan yang stabil ke temperatur relatif rendah (Johnson, dkk., 1999). Pembentukan formasi glass pada kecepatan pendinginan memiliki peran yang sangat penting. Selain itu, penambahan beberapan komponen ke dalam suatu paduan dapat meningkatkan GFA pada BMG. Penelitian tentang BMG Cu-Zr masih sedikit. Ditambah lagi untuk membentuk BMG juga diperlukan pendinginan yang super cepat sehingga dibutuhkan metode yang tepat. Dalam penelitian ini akan dibahas mengenai metode pendinginan super cepat dengan teknik pengecoran cetakan di tembaga 
sebagai pembentuk material BMG. Material yang digunakan ialah paduan $\mathrm{Cu}_{45} \mathrm{Zr}_{45} \mathrm{Al}_{5} \mathrm{Ag}_{5}$ dimana kandungan dasarnya $\mathrm{Cu}-\mathrm{Zr}$. Metode pendinginan ini melibatkan proses suction pump dan arc melting.

\section{Metode}

Dalam penelitian ini terdapat tiga langkah untuk memperoleh BMG. Pertama, persiapan sampel dari berbagai elemen dengan kemurnian tinggi. Kedua, pembentukan BMG dengan metode pendinginan super cepat dengan bantuan mesin suction. Dan ketiga, menganalisa sampel dengan karakterisasi untuk pembuktian bahwa sampel merupakan BMG.

\subsection{Persiapan Sampel BMG}

Paduan $\mathrm{Cu}_{45} \mathrm{Zr}_{45} \mathrm{Al}_{5} \mathrm{Ag}_{5}$ dipersiapkan dengan kemurnian logam yang tinggi pada $\mathrm{Cu}, \mathrm{Zr}$, $\mathrm{Al}$, dan $\mathrm{Ag}$ (kemurnian di atas 99,9\% berat). Permukaan sampel dibersihkan dengan acetone, acid, dan alkohol untuk menghilangkan debu, kotoran sisa dan oksida. Sebagaimana komposisi BMG $\mathrm{Cu}_{45} \mathrm{Zr}_{45} \mathrm{Al}_{5} \mathrm{Ag}_{5}$, dipersiapkan setiap unsur dalam atomik \% yaitu $\mathrm{Cu}-45 \%, \mathrm{Zr}-45 \%$, Al-5\%, dan Ag-5\%. Total massa yang digunakan adalah $3 \pm 0.0009$ gram. Setelah dicelupkan dalam ketiga larutan, sampel dijaga agar kering dan tidak lembab dengan cara penyerapan menggunakan tisu kering sehingga menjadi mengkilap. Campuran dari logam $\mathrm{Cu}, \mathrm{Zr}, \mathrm{Al}$, dan $\mathrm{Ag}$ murni diletakkan dalam wadah tembaga seperti Gambar 2 dengan urutan dari atas ke bawah yaitu $\mathrm{Zr}, \mathrm{Cu}, \mathrm{Ag}$, dan $\mathrm{Al}$. Tujuan pengurutan letak ialah untuk memperoleh perubahan wujud dari padat ke cair secara merata. Diharapkan ketika busur dari elektroda terfokus pada campuran logam, komponen satu akan saling menyatu dengan komponen lain sehingga paduan akan homogen. Paduan yang terbentuk berupa oval setelah proses argon arc melting. Penggunaan argon berfungsi untuk menghindari terbentuknya efek oksida paduan pada lingkungan dengan temperatur tinggi. Paduan ini dilelehkan secara berulang selama 4 kali bolak-balik untuk mencapai bentuk homogennya. Produk yang dihasilkan harus memiliki bentuk yang mengkilap tanpa ada pengotor di permukaan.

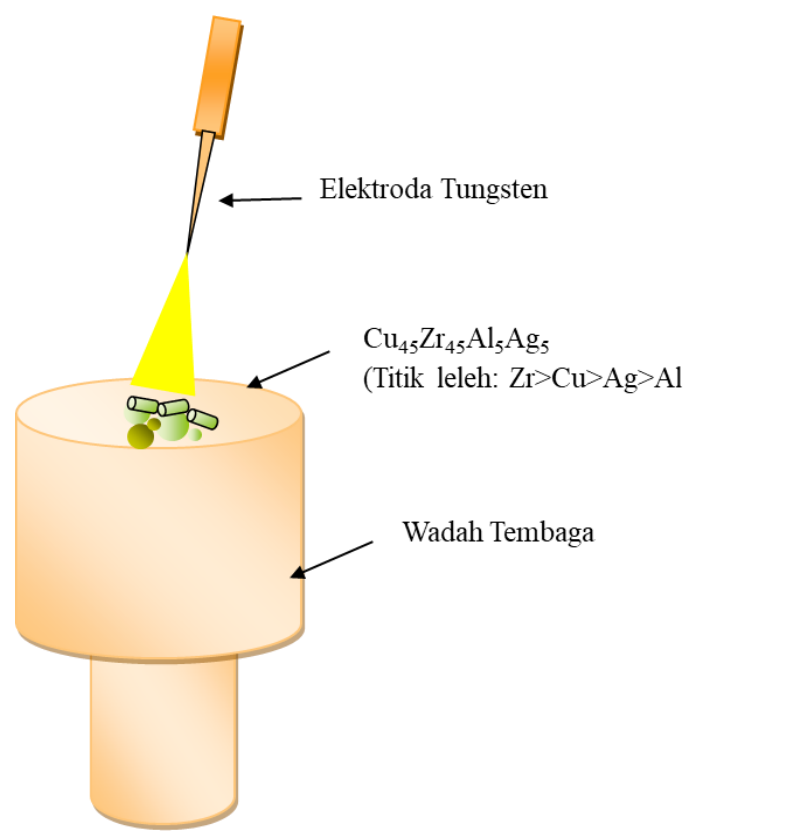

Gambar 2: Arc Melting pada Elemen Logam Paduan $\mathrm{Cu}_{45} \mathrm{Zr}_{45} \mathrm{Al}_{5} \mathrm{Ag}_{5}$ di Wadah Tembaga

\subsection{Pembentukan BMG}

Tahap persiapan yaitu dengan menghubungkan wadah tembaga yang sudah diberi pendinginan ke saluran penghisap (suction). Tujuan penggunaan saluran suction ialah mempercepat leburan paduan $\mathrm{Cu}_{45} \mathrm{Zr}_{45} \mathrm{Al}_{5} \mathrm{Ag}_{5}$ menuju wadah tembaga yang sudah diberi pendinginan. Dengan demikian, terjadi pendinginan yang super cepat yakni dari temperatur lebur paduan saat proses arc melting (di atas 1500 


\section{Studi Metode Pendinginan Super Cepat untuk Pembentukan Bulk Metallic Glasses pada Paduan $\mathrm{Cu}_{45} \mathrm{Zr}_{45} \mathrm{Al}_{5} \mathrm{Ag}_{5}$}

${ }^{\circ} \mathrm{C}$ ) hingga temperatur di bawah beku saat leburan menyentuh wadah tembaga yang dingin (di bawah $25^{\circ} \mathrm{C}$ ). Cetakan paduan ditahan menggunakan kasa besi sebelum saluran suction dengan tujuan untuk menghalangi paduan terhisap hingga ke mesin suction.

Tahap pengerjaan yaitu meleburkan kembali paduan yang sudah berbentuk oval. Hasil peleburan paduan tersebut secara cepat dihisap oleh mesin suction dengan pendinginan yang super cepat menggunakan mesin pendingin di bawah temperatur $-25^{\circ} \mathrm{C}$. Cetakan paduan menjadi dingin seketika dan mengisi dies. Sistem sirkulasi pendinginan seperti yang ditunjukkan pada Gambar 3. Proses pembentukan BMG dibantu dengan gas argon dengan maksud untuk menghindari oksidasi berlebih akibat pengaruh logam dalam komposisinya pada temperatur tinggi. Dengan metode pengecoran menggunakan wadah tembaga, dihasilkan sampel dengan bentuk batang silinder yang memiliki dimensi diameter $2 \mathrm{~mm}$ hingga menjadi $4 \mathrm{~mm}$ dan panjang $30 \mathrm{~mm}$.

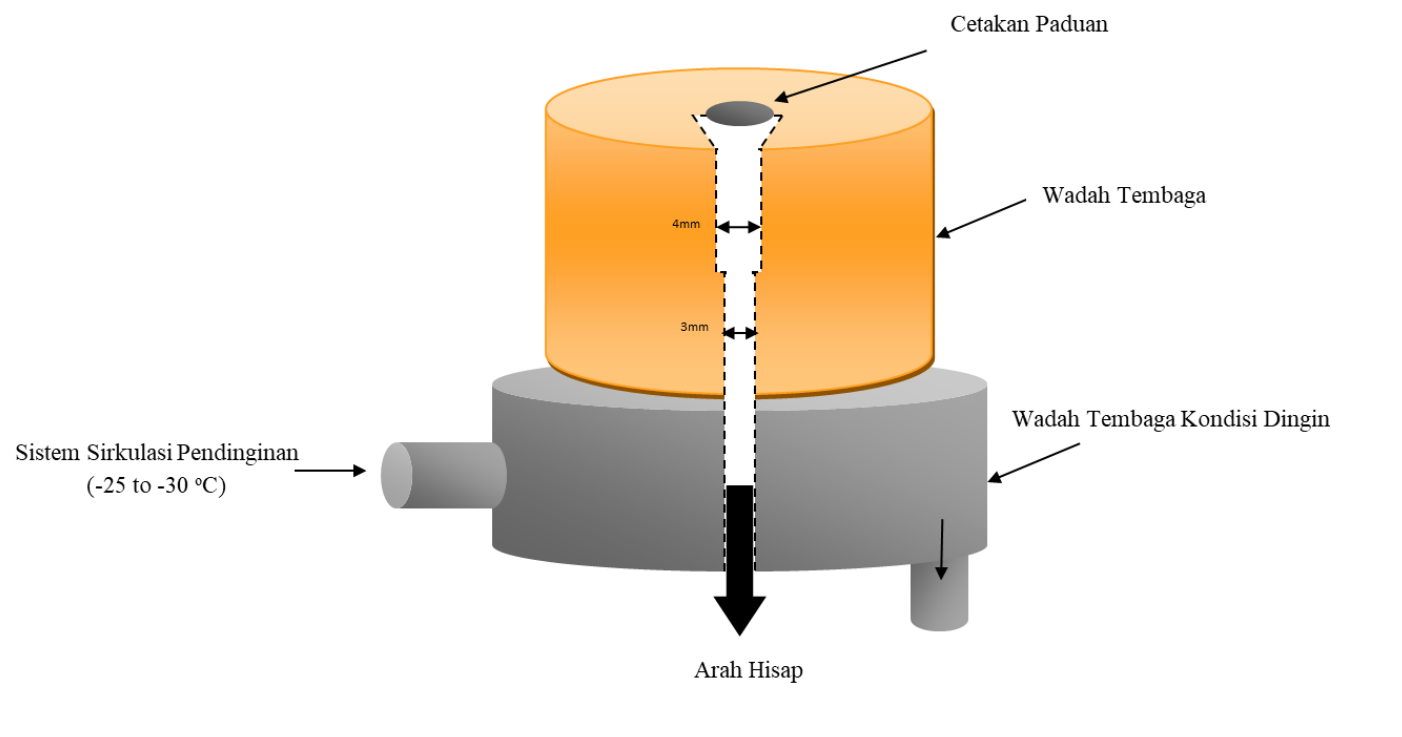

Gambar 3: Sistem Sirkulasi Pendinginan

Kemudian dilakukan pemotongan menjadi sampel dengan bentuk disk (dengan diameter 4mm dan ketebalan 1mm) menggunakan mesin potong diamond cutter (Secotom-10, Struers, Denmark). Hasil pemotongan sampel berbentuk disk diamplas hingga halus dari 800-mesh sampai 4000-mesh. Kemudian pemolesan dilakukan menggunakan serbuk alumina dengan diameter partikel $1 \mu \mathrm{m}$ dan 0.3 $\mu \mathrm{m}$ lalu dilarutkan dalam deionized water sehingga menghasilkan permukaan yang halus dan bebas goresan. Setelah dilakukan pengamplasan dan pemolesan, mesin ultrasonic vibratory polisher (VibroMet ${ }^{\circledR}$ 2, Buehler, U.S.A.) digunakan untuk pemolesan lanjut agar mendapatkan permukaan sampel yang lebih jelas.

\subsection{Analisa}

Untuk memastikan sampel bulk memiliki struktur amorfus, morfologi permukaan dievaluasi menggunakan Scanning Electron Microscopy (SEM) (HITACHI TM3000, Jepang). Energy Dispersion Spectrometer (EDS) digunakan untuk menentukan komposisi dari BMG. Analisa kuantitatif diambil 3-5 titik kemudian dirata-ratakan hasilnya. Stabilitas termal dari sampel juga diperiksa menggunakan Differential Scanning Calorimetry (DSC) dengan TA Instrument DSC Q20. Struktur internalnya diverifikasi menggunakan $X$-ray diffraction (XRD) dengan Bruker D2 PHASER $X$-ray Diffractometer $(\lambda=0.154 \mathrm{~nm})$ untuk memastikan keberadaan fasa amorfusnya. Analisa karakterisasi ditekankan pada pengambilan posisi atas, tengah, dan bawah sampel.

\section{Hasil dan Pembahasan}


Gambar 4 menunjukan struktur metalografi permukaan berbagai posisi yang diambil menggunakan SEM dengan mode Backscatter Electron Image (BEI) dari paduan tembaga-zirkonium $\mathrm{Cu}_{45} \mathrm{Zr}_{45} \mathrm{Al}_{5} \mathrm{Ag}_{5}$ pada perbesaran 5000 kali. Dengan mengamati gambar BEI-nya, paduan silinder ini tidak memiliki fasa presipitasi kristal pada permukaannya baik pada posisi atas, tengah, maupun bawah. Analisa komposisi paduan dianalisa menggunakan EDS yang merupakan bagian dari mesin SEM. Hasil analisa komposisi pada Gambar 5 dan Tabel 1 mengindikasikan perbedaan atomik persen yang sedikit dibandingkan dengan komposisi paduan $\mathrm{Cu}_{45} \mathrm{Zr}_{45} \mathrm{Al}_{5} \mathrm{Ag}_{5}$ dengan komposisi $45 \mathrm{at} . \% \mathrm{Cu}$, $45 \mathrm{at} . \% \mathrm{Zr}$, 5at.\%Al, dan 5at.\%Ag. Keberagaman komposisi tiap elemen di posisi atas, tengah, dan bawah tidak menunjukkan perbedaan yang signifikan.
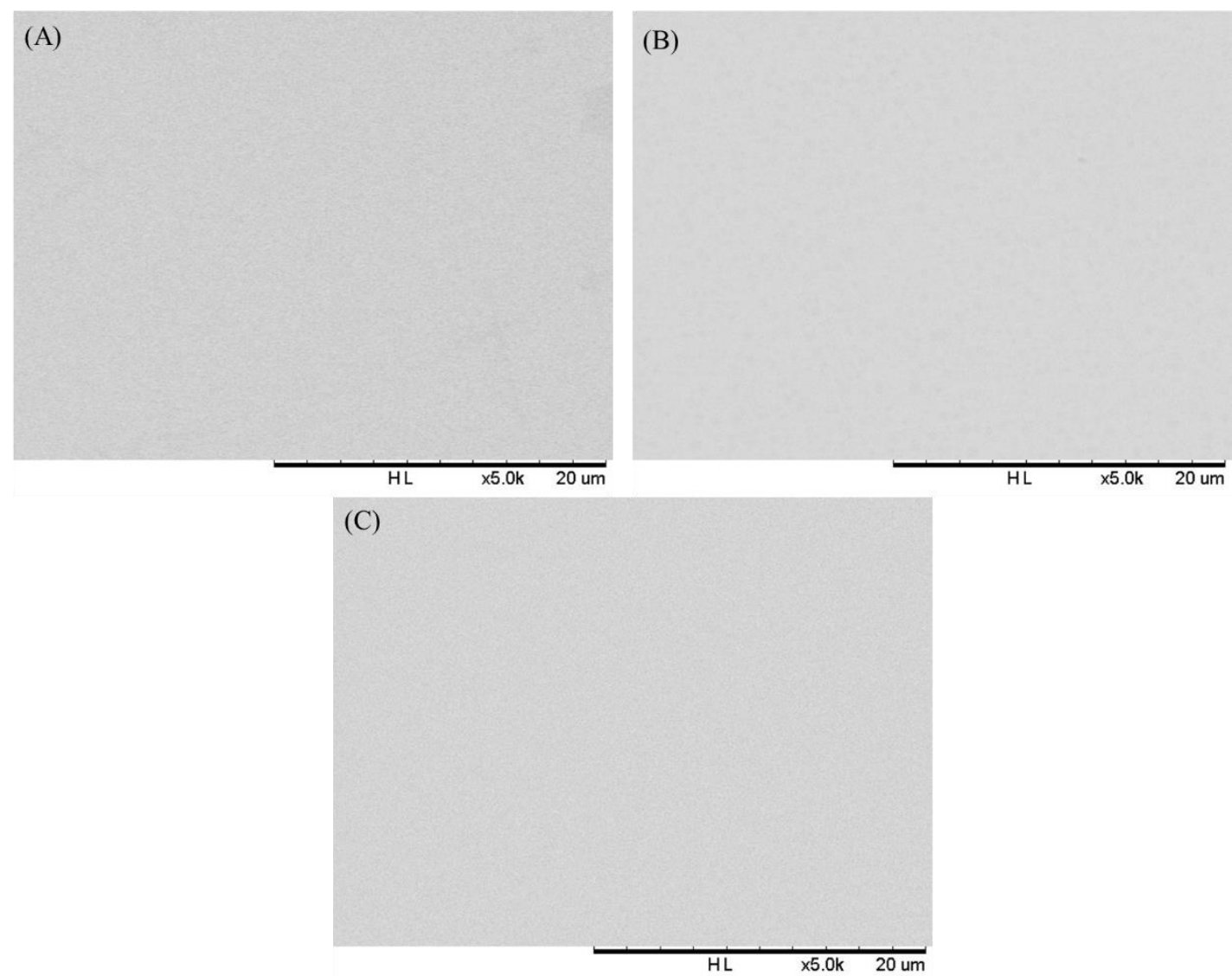

Gambar 4: Hasil SEM pada BMG Paduan $\mathrm{Cu}_{45} \mathrm{Zr}_{45} \mathrm{Al}_{5} \mathrm{Ag}_{5}$ Posisi (A) Atas, (B) Tengah, dan (C) Bawah

Tabel 1: Hasil Analisa Komposisi EDS pada BMG Paduan $\mathrm{Cu}_{45} \mathrm{Zr}_{45} \mathrm{Al}_{5} \mathrm{Ag}_{5}$

\begin{tabular}{ccc}
\hline Posisi & Elemen & at.\% \\
\hline \multirow{4}{*}{ Atas } & $\mathrm{Zr}$ & 43,92 \\
& $\mathrm{Cu}$ & 46,86 \\
& $\mathrm{Ag}$ & 4,52 \\
\multirow{4}{*}{ Tengah } & $\mathrm{Al}$ & 4,70 \\
\hline & $\mathrm{Zr}$ & 45,30 \\
& $\mathrm{Cu}$ & 44,53 \\
& $\mathrm{Ag}$ & 4,61 \\
& $\mathrm{Al}$ & 5,56 \\
\hline & $\mathrm{Zr}$ & 44,69 \\
& $\mathrm{Cu}$ & 44,50
\end{tabular}


Studi Metode Pendinginan Super Cepat untuk Pembentukan Bulk Metallic Glasses pada Paduan $\mathrm{Cu}_{45} \mathrm{Zr}_{45} \mathrm{Al}_{5} \mathrm{Ag}_{5}$

Bawah Ag $\quad 4,75$

$\mathrm{Al} \quad 6,06$

Gambar 6 menunjukkan kurva analisa termal DSC dari BMG paduan $\mathrm{Cu}_{45} \mathrm{Zr}_{45} \mathrm{Al}_{5} \mathrm{Ag}_{5}$. Setelah pengamatan dilakukan, temperatur puncak kristalisasi $\left(\mathrm{T}_{\mathrm{x}}\right)$ terjadi pada $765 \mathrm{~K}$ dan (Glassy Temperature) $\mathrm{T}_{\mathrm{g}}$ yaitu $637 \mathrm{~K}$. Dari gambar, dapat ditemukan juga bahwa pada saat perubahan fasa terjadi, panas dari kristalisasi terlepaskan, dan aliran panas pada puncak eksotermik berubah secara signifikan. Dapat disimpulkan bahwa proporsi amorfus dalam metallic glass sangat mempengaruhi terbentuknya titik puncak eksotermik yang tinggi dan tajam. Perbandingan temperatur $\mathrm{T}_{\mathrm{g}}$ dan temperatur rekristalisasi atau $\mathrm{T}_{\mathrm{x}}$ diukur menggunakan DSC (Zhang dkk., 2007). Temperatur transisi glass pada komposisi metalic glass yang sama adalah $\mathrm{T}_{\mathrm{g}}=697 \mathrm{~K}$ dan temperatur onset kristalisasinya adalah $\mathrm{T}_{\mathrm{x}}=768 \mathrm{~K}$. Hasil analisa DSC termal pada Zhang dkk. serupa dengan yang didapatkan pada penelitian ini.
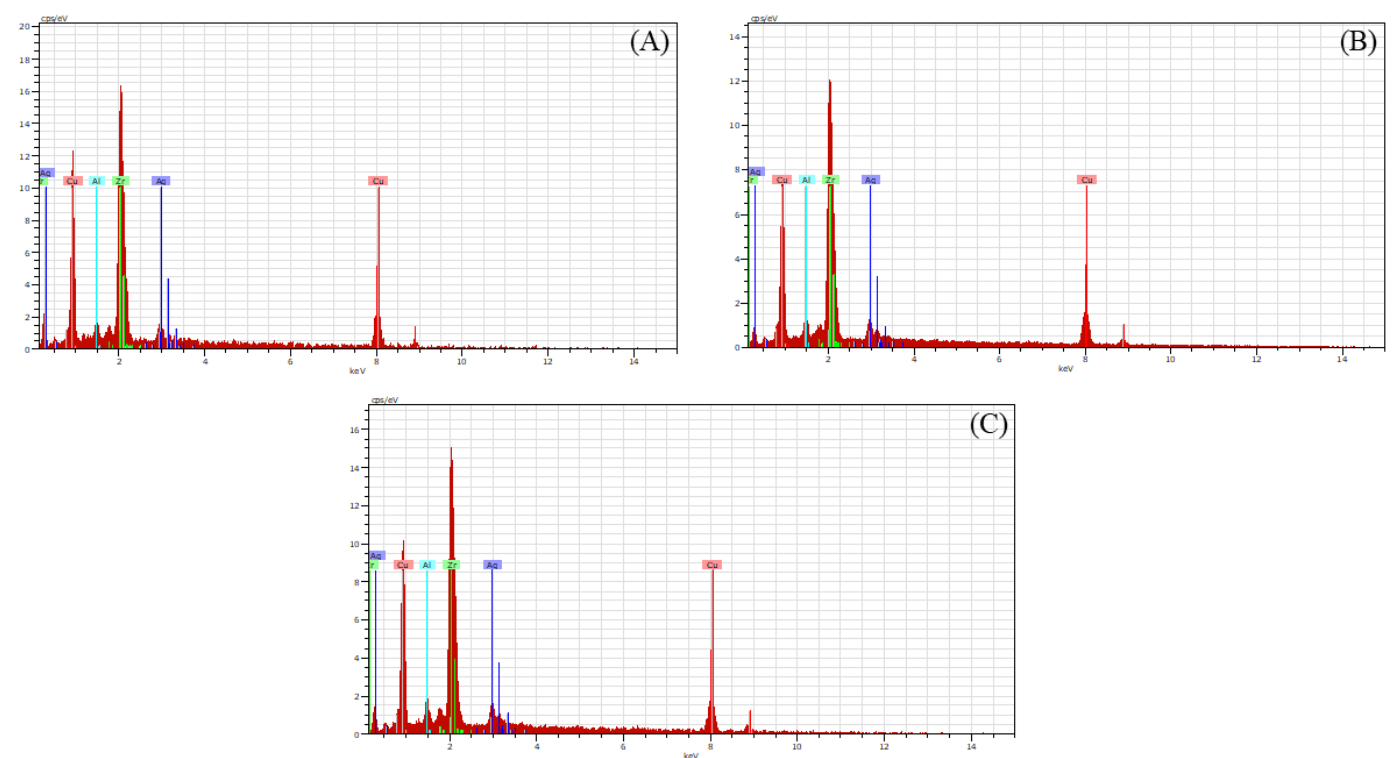

Gambar 5: Hasil Grafik EDS pada BMG Paduan $\mathrm{Cu}_{45} \mathrm{Zr}_{45} \mathrm{Al}_{5} \mathrm{Ag}_{5}$ posisi (A) Atas, (B) Tengah, dan (C) Bawah

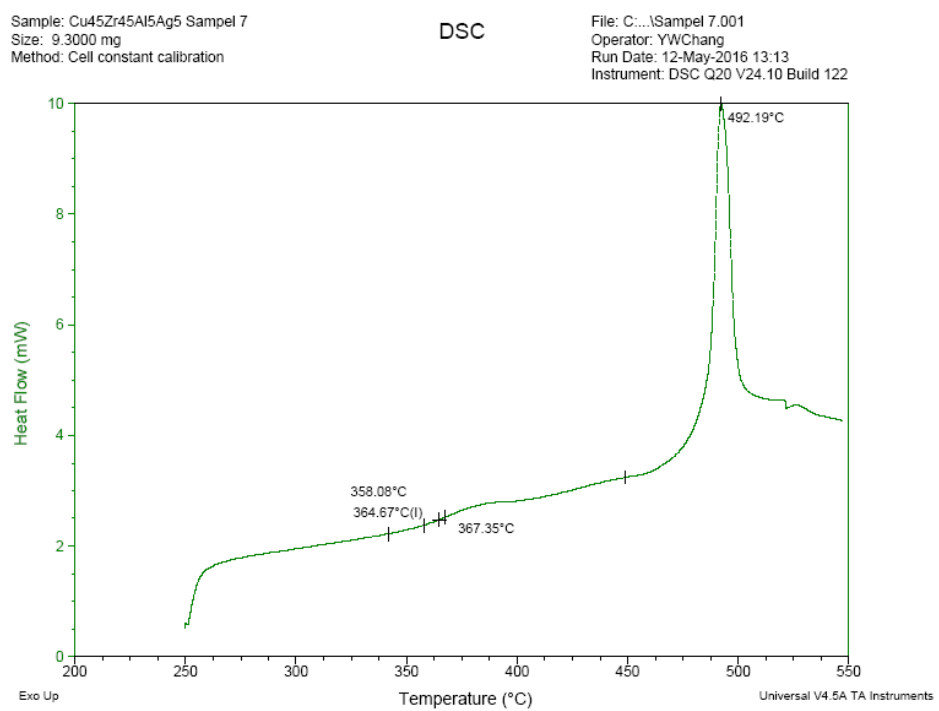

Gambar 6: Hasil Grafik DSC pada BMG Paduan $\mathrm{Cu}_{45} \mathrm{Zr}_{45} \mathrm{Al}_{5} \mathrm{Ag}_{5}$ Semua Posisi 
Untuk membuktikan lebih lanjut bahwa sampel yang dibuat merupakan material amorfus, paduan logam ini dipotong dan dilakukan analisa permukaan dengan menggunakan XRD. Pola XRD dari paduan $\mathrm{Cu}_{45} \mathrm{Zr}_{45} \mathrm{Al}_{5} \mathrm{Ag}_{5}$ ditunjukkan pada Gambar 7. Dari pola difraksi XRD tersebut dari Gambar 7(A)-(C), tidak menunjukkan adanya crystal diffraction. Dengan ditemukan adanya puncak emisi, pola difraksi menunjukkan titik puncak yang lebar. Sehinga, dapat dipastikan bahwa sampel ini sedikit memiliki fasa kristalisasi. Analisa XRD menggunakan software Bruker AXS diffract.EVA V.4.1 untuk menghitung kristalinitas dilakukan menghasilkan laju pembentukan amorfus (dalam persen) mencapai diatas $70 \%$. Ini membuktikan bahwa paduan merupakan metallic glass dengan struktur amorfus. Sehingga sampel yang digunakan merupakan paduan amorfus. Analisa amorfus menurut posisi, nilai terbesar terdapat pada posisi bawah, yaitu 79,7\%. Sedangkan pada posisi tengah amorfus menurun menjadi $78,7 \%$. Dan akhirnya paling rendah pada posisi atas, yaitu $76,6 \%$. Hal ini mengindikasikan bahwa leburan paduan mengisi cetakan dari bawah hingga atas dimana kecepatan pedinginan tercepat dimiliki bagian paling bawah. Semakin ke atas posisinya maka kecepatan pendinginan semakin menurun sehingga amorfus yang terbentuk semakin sedikit. Banyak sedikitnya jumlah amorfus menandai seberapa besar peluang metallic glass dapat terbentuk.
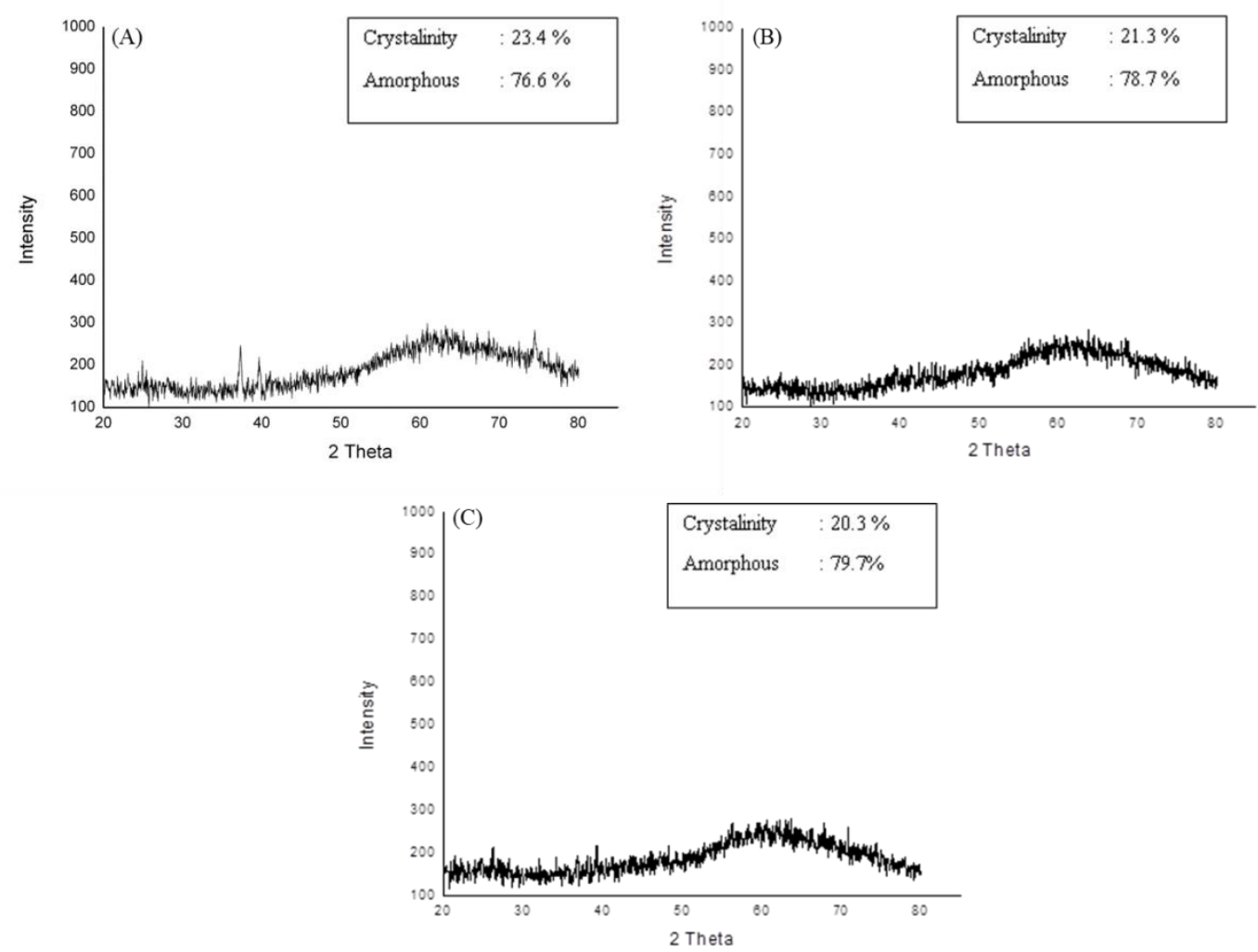

Gambar 7: Hasil Grafik XRD pada BMG Paduan $\mathrm{Cu}_{45} \mathrm{Zr}_{45} \mathrm{Al}_{5} \mathrm{Ag}_{5}$ posisi (A) Atas, (B) Tengah, dan (C) Bawah

\section{Kesimpulan}

Pada penelitian ini, argon arc melting dan pengecoran cetakan dengan wadah tembaga digunakan untuk menghasilkan sampel BMG paduan $\mathrm{Cu}_{45} \mathrm{Zr}_{45} \mathrm{Al}_{5} \mathrm{Ag}_{5}$. Metode yang digunakan ialah pendinginan super cepat pada paduan dari temperatur lebur di atas $1500^{\circ} \mathrm{C}$ hingga temperatur di bawah $-25^{\circ} \mathrm{C}$. Analisa permukaan morfologi perbesaran 5000 kali pada sampel mengindikasi bahwa tidak ditemukan presipitasi kristal baik pada posisi atas, tengah, dan bawah. Hasil komposisi pada analisa EDS menunjukkan tidak menunjukan perbedaan signifikan yang artinya sampel BMG masih konsisten terhadap komposisi asalnya 45at.\%Cu, 45at.\%Zr, 5at.\%Al, dan 5at.\%Ag. Kurva analisa termal DSC ditemukan puncak $\mathrm{T}_{\mathrm{x}}(765 \mathrm{~K})$ dan $\mathrm{T}_{\mathrm{g}}(637 \mathrm{~K})$. Analisa amorfus XRD ditemukan nilai tertinggi pada 
Studi Metode Pendinginan Super Cepat untuk Pembentukan Bulk Metallic Glasses pada Paduan $\mathrm{Cu}_{45} \mathrm{Zr}_{45} \mathrm{Al}_{5} \mathrm{Ag}_{5}$

posisi bawah yaitu sebesar $79,7 \%$. Semakin ke atas posisinya maka kecepatan pendinginan semakin menurun sehingga amorfus yang terbentuk semakin sedikit.

\section{Acknowledgments}

Penulis mengucapkan terimakasih kepada Ministry of Science and Technology (MOST 104-2628-E011-001-MY3) Taiwan atas pendanaan yang diberikan sehingga penelitian ini dapat dilakukan dengan baik.

\section{Referensi}

A. Inoue, N. Nishiyama, Mater. Sci. Eng. A 226-228 (1997) 401.

Kai, W., Ren, F., Kao, P. C., Wang, R. F., Chuang, C. P., Freels, M. W., Liaw, P. K.. (2009) 'Air- Oxidation of a Cu45Zr45Al5Ag5 Bulk Metallic Glass', Advanced Engineering Materials, Volume 11(5), pp. 380-386

Nishikawa, H., WongPiromsarn, K., Abe, H., Takemoto, T., Fukuhara, M., Inoue, A. (2009) 'Solderability of Bulk Metallic Glasses Using Lead-free Solders’, Materials Transactions, Volume 50(6), pp. 1326-1329

Suryanarayana, C., Inoue, A. (2011) ‘Bulk Metallic Glasses', CRC Press, USA

Wang, W. H., Dong, C., Shek, C. H. (2004) 'Bulk Metallic Glasses', Materials Science and Engineering: R: Reports, Volume 44(2), pp. 45-89

W.L. Johnson, MRS Bull. 24 (10) (1999) 42.

Zhang, W., Jia, F., Zhang, Q., Inoue, A. (2007) 'Effects of Additional Ag on the Thermal Stability and Glassforming Ability of Cu-Zr Binary Glassy Alloys', Materials Science and Engineering: A, Volume 459(1), pp. $330-336$ 